\title{
PENGARUH KOMITMEN ORGANISASI TERHADAP KINERJA PERANGKAT NAGARI DALAM PENGELOLAAN KEUANGAN NAGARI DI KECAMATAN X KOTO SINGKARAK DAN JUNJUNG SIRIH
}

\author{
Yelsa Noviza ${ }^{1}$ \\ Jurusan Administrasi Publik,Fakultas Ilmu Sosial, Universitas Negeri Padang \\ Jl. Kakak Tua No.23 Air Tawar Barat, Padang. Hp. 082386145859 \\ Email:yelsanoviza@gmail.com,
}

\begin{abstract}
This study aimed to determine the influence of commitment organization on performance of nagari government apparatus in managing nagari finance in X Koto Singkarak District Junjung Sirih. This research uses quantitative methods with the form of associative research. The population is all the nagari in the two sub-districts, as many as 70 respondents from the nagari device. The sample was 68 respondents determined by the Slovin formula and a $2 \%$ error rate using the multi stage random sampling technique. Data collection techniques in this study used questionnaires distributed to respondents with Likert scale measurements. Dataof this study were analyzed using multiple linear regression test. The results show that the effect of the affective commitment variable on the performance of nagari devices in nagari financial management is 5.7\%. normative on the performance of nagari devices in managing nagari finances by 6.4\%. Together, the influence of the three cariables was on the performance of nagari devices in nagari financial management in District X Koto Singkarak and Junjung Sirih at $10.8 \%$. So it was concluded that the organizational commitment of nagari devices had a significant effect on the performance of nagari devices in managing financial nagari.
\end{abstract}

Keywords:Commitment organization, job performance, finance management

\begin{abstract}
ABSTRAK
Penelitian ini bertujuan untuk mengetahui pengaruh komitmen organisasi terhadap kinerja perangkat nagari dalam pengelolaan keuangan nagari di Kecamatan X Koto Singkarak dan Junjung Sirih. Penelitian ini menggunakan metode kuantitatif dengan bentuk penelitian asosiatif. Populasinya adalah seluruh nagari yang ada di dua kecamatan tersebut yaitu sebanyak 70 responden perangkat nagari. Sampelnya adalah sebanyak 68 responden ditentukan dengan rumus slovin dan tingkat kesalahan $2 \%$ menggunakan teknik multi stage random sampling. Dalam penelitian ini menggunakan teknik pengumpulan data dengan angket yang disebarkan kepada responden dengan pengukuran skala likert. Kemudian data dianalisis dengan menggunakan regresi linear berganda. Berdasarkan analisis data yang telah dilakukan didapatkan hasil penelitian bahwa pengaruh variabel komitmen afektif terhadap kinerja perangkat nagari dalam pengelolaan keuangan nagari adalah sebesar 5,7\%, pengaruh variabel komitmen kontinuitas terhadap kinerja perangkat nagari dalam pengelolaan keuangan nagari sebesar 8,5\%, dan pengaruh komitmen normatif terhadap kinerja perangkat nagari dalam pengelolaan keuangan nagari sebesar 6,4\%. Secara bersama-sama pengaruh ketiga variabel tersebut terhadap kinerja perangkat nagari dalam pengelolaan keuangan nagari di Kecamatan X Koto Singkarak dan Junjung Sirih sebesar 10,8\%. Sehingga disimpulkan bahwa komitmen organisasi perangkat nagari berpengaruh secara signifikan terhadap kinerja perangkat nagari dalam pengelolaan keuangan nagari.
\end{abstract}

Kata Kunci: Komitmen Organisasi, Kinerja, Pengelolaan Keuangan Nagari

Pendahuluan
Dewasa ini, pemerintah Indonesia sedang berupaya menggencarkan 
pembangunan desa. Sesuai dengan Nawacita Jokowi-JK yaitu membangun dari desa. Dimana poros perubahan itu berawal dari desa dan kemudian menjalar ke Kota dan Provinsi.

Dalam Undang-Undang Nomor 6 Tahun 2014 pasal 1 ayat 1 telah dijelaskan bahwa desa telah memiliki kewenangan untuk mengatur dan mengurus urusan pemerintahannya sendiri. Dalam Peraturan Daerah Provinsi Sumatera Barat Nomor 7 Tahun 2018 tentang Nagari dijelaskan bahwa Nagari adalah Kesatuan Masyarakat Hukum Adat secara geneologis dan historis, memiliki batas-batas dalam wilayah tertentu, memiliki harta kekayaan sendiri, berwenang memilih pemimpinnya secara musyawarah serta mengatur dan mengurus kepentingan masyarakat setempat berdasarkan filosofi dan sandi adat, Adat Basandi Syara' - Syara' Basandi Kitabullah dan/atau berdasarkan asal usul dan adat istiadat setempat dalam wilayah Provinsi Sumatera Barat. Untuk mengatur dan mengurus desa, pemerintah telah mengganggarkan APBN (alokasi dana desa) bagi setiap desa di Indonesia dengan total kurang lebih Rp 1 Miyar. penggunaan dana desa terbagi atas belanja aparatur dan operasional pemerintahan desa sebesar $30 \%$ dan untuk pemberdayaan masyarakat sebesar $70 \%$.
Dalam Peraturan Menteri Dalam Negeri Nomor 113 Tahun 2014 tentang Pengelolaan Keuangan Desa, dijelaskan bahwa Pengelolaan Keuangan Desa ialah keseluruhan kegiatan yang meliputi perencanaan, pelaksanaan, penatausahaan, pelaporan, dan pertanggungjawaban keuangan desa. Kemudian dijelaskan bahwa keuangan desa dikelola berdasarkan asas-asas transparan, akuntabel, partisipatif serta dilakukan dengan tertib dan disiplin anggaran Pengelolaan keuangan nagari di kelola dalam masa satu tahun anggaran yakni mulai tanggal 1 Januari sampai dengan tanggal 31 Desember.

Sumber daya manusia adalah unsur yang sangat penting dalam sebuah organisasi. Agar tujuan organisasi dapat tercapai dengan baik, diperlukan sumber daya manusia yang berkomitmen, bertanggung jawab dan bersungguhsungguh dalam menyelesaikan pekerjaannya dan haruslah berkomitmen tinggi dan memiliki tekad yang kuat untuk menyelesaikan pekerjaannya. Walaupun dalam mengelola keuangan nagari telah diatur sedemikian rupa, masih terdapat berbagai permasalahan dalam pengelolaan keuangan nagari.

Bukti permasalahan tersebut yaitu pada pertengahan tahun 2017 di Kecamatan X Koto Singarak tepatnya di Nagari Aripan tertangkap tangan dua 
perangkat Nagari Sekretaris Nagari dan Kepala Seksi Pemerintahan yang melakukan pungli terhadap warga setempat dalam pembuatan sertifikat Prona. Sementara kegiatan proyek operasi nasional agraria (prona) telah dibiayai oleh APBN. Kedua perangkat nagari tersebut diamankan Tim Saber Pungli Polres Solok dan terancam kurungan minimal 1 tahun maksimal 20 tahun, sebagaimana diatur dalam Undang-Undang RI No.20 Tahun 2001 pasal 11 dan 12, tentang Pemberantasan Korupsi (sumbarsatu.com, 2017). Bupati Solok H.Gusmal SE.MM menjelaskan bahwa dana di Pemerintah Nagari belum mampu menjawab tujuan dari pemerintah yakni terwujudnya desa/nagari yang maju dan mandiri (mediaharapan.com, 2017)

Selanjutnya berdasarkan hasil wawancara pada hari Kamis 10 Januari 2019 menurut Sekretaris Nagari Kacang kendala dalam pengelolaan keuangan nagari yaitu format pelaporan keuangan yang selalu diganti tiap tahunnya, dan aturan yang selalu berganti serta lambatnya sistem di dinas terkait. Kurangnya pembenahan terhadap perangkat nagari sehingga perangkat nagari tidak mampu mengelola dana tersebut dengan semestinya. Susah untuk menjalin kerjasama dengan masyarakat karena kebanyakan masyarakat tidak percaya terhadap kinerja perangkat nagari. Kemudian Sekretaris Nagari Saning Baka juga mengungkapkan bahwa regulasi dari aturan sering terlambat dan aturan tersebut tidak menjabarkan maksud undang undang dengan jelas. Adanya perangkat nagari yang kurang bersungguh-sungguh dalam melaksanakan tugas dan tanggung jawabnya, sering perangkat nagari datang terlambat dan lewat dari jam masuk kantor. Sehingga hal tersebut berpengaruh terhadap pekerjaan.

Berdasarkan hasil penelitian yang penulis temukan terdapat pengaruh komitmen organisasi terhadap kinerja seperti penelitian Amirul Akbar,dkk (2015) Hasil penelitian ini menyatakan bahwa Komitmen afektif dan komitmen normatif secara bersama-sama (simultan) berpengaruh positif dan signifikan terhadap kinerja dengan uji f. Uji t (parsial) komitmen afektif dan normatif berpengaruh positif dan signifikan, namun ada variabel bebas komitmen kontinuitas secara parsial berpengaruh positif dan tidak signifikan terhadap kinerja. Ranty Sapitri (2016) Hasil penelitian ini menyatakan bahwa terdapat hubungan yang kuat antara komitmen organisasi dengan kinerja. Presentasi pengaruh komitmen organisasi terhadap kinerja $38,1 \%$. Komitmen organisasi berpengaruh secara signifikan. 
Adapun rumusan masalah yang di bahas dalam penelitian ini adalah:

1. Apakah terdapat pengaruh komitmen organisasi (komitmen afektif, komitmen koninuitas, komitmen normatif) terhadap kinerja perangkat nagari dalam pengelolaan keuangan nagari di Kecamatan X Koto Singkarak dan Junjung Sirih ?

2. Apakah terdapat pengaruh komitmen afektif, komitmen kontinuitas dan komitmen normatif secara parsial terhadap kinerja perangkat nagari dalam pengelolaan keuangan nagari di Kecamatan X Koto Singkarak dan Junjung Sirih?

\section{Tinjauan Kepustakaan}

\section{Komitmen organisasi dan kinerja}

Menurut Mayer dan Allen (1984) komitmen organisasi secara umum dapat diartikan sebagai hubungan psikologis antar karyawan dan organisasinya yang membuatnya kurang memungkinkan bahwa karyawan secara sukarela akan meninggalkan organisasi meski bagaimanapun keadaan organisasi tersebut. Secara luas komitmen organisasi diartikan sebagai sikap kerja yang multidimensi . Menurut Luthan (2006) (dalam Arina Nurandini, 2014) komitmen organisasi adalah suatu tekad yang kuat untuk tetap menjadi anggota sebuah organisasi, tekad untuk berjuang keras sesuai dengan tujuan organisasi, serta kepercayaan tertentu dan dengan lapang hati menerima nilai dan tujuan organisasi tersebut. Selanjutnya menurut Ivancevich, Konopasuke dan Matteson (2007) (dalam Jajang Adiftiya, 2014) komitmen organisasi sebagai rasa kesungguhan terhadap tujuan organisasi, perasaan ikut serta terlibat dalam tugastugas organisasi dan perasaan setia terhadap organisasi.

Kemudian menurut Robbins (2008) dan Meyer dan Allen (2002) komitmen organisasi terbagi tiga, yaitu komitmen afektif menunjukan adanya suatu keterikatan emosional dan keterlibatan langsung dalam organisasi, komitmen kontinuitas (berkelanjutan) menunjukkan adanya pertimbangan biaya jika tidak lagi dalam organisasi tersebut, dan komitmen normatif mencerminkan persepsi kewajiban untuk tetap berada dalam organisasi.

Berdasarkan ungakapan para ahli di atas dapat disimpukan bahwa komitmen organisasi adalah kesungguhan dan keinginan yang kuat dari dalam diri karyawan untuk mencapai tujuan organisasi, dimana adanya ikatan emosional terhadap organisasi, keinginan untuk tetap bertahan dalam suatu organisasi tertentu dan penerimaan nilai- 
nilai serta tujuan organisasi. Hal terpenting dalam komitmen organisasi ini adalah keloyalan dan kesungguhan dengan melibatkan diri secara penuh dalam kelangsungan organisasi.

Selanjutnya, Kinerja berasal dari kata Job performance atau actual performance yang berarti prestasi kerja atau prestasi sesungguhnya yang dicapai oleh seseorang. Bisa dikatakan kinerja adalah hasil kerja secara kualitas dan kuantitas yang dicapai oleh seseorang pegawai dalam melaksanakan fungsinya sesuai tanggung jawabnya (Bintoro, 2017). Menurut Robbins dalam Bintoro (2017) kinerja adalah upaya yang dihasilkan oleh individu terhadap pekerjaannya. Di sisi lain Sinambela, dkk dalam Bintoro (2017) menjelaskan kinerja pegawai adalah kemampuan dalam melakukan sesuatu keahlian tertentu. Kinerja pegawai sangat penting, karena dengan melihat kinerja dapat diketahui seberapa jauh kemampuan pegawai dalam melaksanakan tugasnya. Kemudian, menurut Edison dkk (2016) kinerja adalah sesuatu yang dihasilkan dari proses yang dapat diukur selama periode waktu tertentu berdasarkan ketentuan atau kesepakatan yang telah ditetapkan sebelumnya.

Adapun faktor-faktor yang turut mempengaruhi kinerja Menurut Stress (dalam Edi, 2009) faktor-faktor yang mempengaruhi prestasi kerja adalah: a. Kemampuan, perangai, dan minat seorang pekerja. b.Kejelasan dan penerimaan atas penjelasan peranan seorang pekerja.c. Tingkat motivasi kerja. Amstrong dan Barong dalam Sedarmayanti (2011:223) menjelaskan kinerja dapat dipengaruhi oleh 5 (lima) faktor, salah satunya yaitu: Personal factors yang ditunjukkan tingkat keterampilan, kompetensi yang dimiliki, motivasi dan komitmen individu.

Berdasarkan pendapat beberapa para ahli di atas dapat disimpulkan bahwa kinerja adalah sebuah hasil yang diciptakan oleh sesorang baik itu baik atau buruk yang dilahirkan dari proses kerja yang merupakan tanggung jawabnya dalam masa periode tertentu.

\section{Pengelolaan Keuangan Desa/ Nagari}

Dalam pengelolaan keuangan desa/nagari hal yang paling penting adalah sumber daya manusianya sebab SDM sebagai penentu dari jalannya sebuah organisasi. Sukses atau tidaknya dan maju atau mundurnya sebuah organisasi sangat ditentukan oleh SDM di dalamnya. Maka dibutuhkan SDM yang berkomitmen dan bersungguh sungguh, serta bisa diandalkan . Pengertian keuangan desa terdapat dalam Undang-Undang No. 6 Tahun 2014 tentang Desa pasal 1 Ayat 10 dijelaskan bahwa keuangan desa ialah hak dan kewajiban desa yang dapat dinilai dengan uang serta 
segala sesuatu berupa uang dan barang yang berkaitan dengan pelaksanaan hak dan kewajiban desa.

Pengelolaan keuangan desa berpedoman kepada Peraturan Dalam Negeri No. 113 Tahun 2014 tentang Pedoman Pengelolaan Keuangan Desa. Dalam peraturan tersebut dijelaskan bahwa pengelolaan keuangan desa meliputi tahapan perencanaan, pelaksanaan, penata usahaan,pelaporan, pertanggungjawaban keuangan desa, pembinaan dan pengawasan.

Menurut Murtiono (2016: 13) indikator yang digunakan untuk mengukur kinerja kepala desa dalam pengelolaan keuangan desa diantaranya :

1) Transparan, artinya prinsip keterbukaan dimana masyarakat berkemungkinan bisa mendapatkan dan mengetahui akses informasi mengenai pengelolaan keuangan desa atau APB Desa

2) Akuntabel, artinya prisnip dari kewajiban setiap orang guna mempertanggungjawabkan pengelolaan dan pengendalian sumber daya dan pelaksanaan serta kebijakan yang dipercayakan kepadanya untuk mencapai tujuan yang telah ditetapkan.

3) Partisipatif, artinya bahwa dalam pengelolaan keuangan desa harus memberikan ruang seluas-luasnya bagi masyarakat untuk terlibat secara aktif dalam setiap tahapan proses pengelolaan keuangan desa.

4) Tertib dan disiplin anggaran, artinya bahwa APBDesa harus di kelola dengan tepat waktu dan tepat guna serta didukung dengan bukti-bukti administrasi yang bisa dipertanggungjawabkan serta beracuan pada peraturan yang berlaku.

Dalam Peraturan Daerah Provinsi Sumatera Barat Nomor 7 Tahun 2018 tentang Nagari dijelaskan bahwa ketika menjalankan pemerintahan nagari kapalo nagari dibantu oleh perangkatn nagari. Perangkat nagari yang dimaksud terdiri atas Manti Nagari dibantu oleh kapalo urusan, Bandaharo Nagari, Dubalang Nagari dan Kapalo Jorong/Korong.

Namun untuk peraturan daerah Kabupaten Solok, masih memakai Peraturan Daerah No.7 Tahun 2006 tentang pemerintahan nagari. Dalam Perda tersebut dijelaskan bahwa Perangkat Nagari adalah unsur staf dan unsur pelaksana teknis lapangan yang membantu Wali Nagari dalam melaksanakan tugas dan wewenangnya.

Selain itu dalam Bab III Permendagri No. 113 Tahun 2014 Tentang Pedoman Pengelolaan Keuangan Desa dijelaskan bahwa kepala Desa sebagai Kepala Pemerintah Desa adalah pemegang kekuasaan pengelolaan keuangan desa dan 
mewakili pemerintah desa dalam kepemilikan kekayaan desa yang dipisahkan.

\section{Metode Penelitian}

Penelitian ini mengunakan metode penelitian kuantitatif dengan pendekatan yang digunakan yaitu proses, hipotesis, turun ke lapangan, analisa data, menyimpulkan hingga penulisan hasil penelitian menggunakan aspek pengukuran, perhitungan, rumus, dan kepastian data numerik. Dalam penelitian ini populasi adalah semua perangkat nagari yang ada disetiap nagari di Kecamatan $X$ Koto Singkarak dan Junjung Sirih. Sampel

\section{Hasil Penelitian dan Pembahasan}

\section{Temuan Penelitian}

Berdasarkan yang telah dijelaskan pada bagian pendahuluan, maka penelitian ini telah mendapatkan jawaban dari pertanyaan penelitian (rumusan masalah). Pertama yaitu Apakah terdapat pengaruh komitmen organisasi (komitmen afektif, komitmen koninuitas, komitmen normatif) terhadap kinerja perangkat nagari dalam pengelolaan keuangan nagari di Kecamatan X Koto Singkarak dan Junjung Sirih Kabupaten Solok?

Jawaban dari pertanyaan ini dapat diketahui dari hasil analisis data yang telah penulis lakukan, sebagai berikut

dalam penelitian ini berjumlah 68 responden ditentukan dengan menggunakan rumus slovin dengan tingkat kesalahan $2 \%(0,02)$.

Dalam penelitian ini pengumpulan data menggunakan angket dengan pengukuran skala likert dan menggunakan 4 opsi jawaban yaitu sangat setuju, setuju, tidak setuju, sangat tidak setuju. Analisa data menggunakan teknik regresi linear berganda yang di awali dengan uji asumsi klasik seperti yang dipersyaratkan dalam uju regresi. Untuk memperoleh gambaran umum mengenai kedua variabel juga digunakan frekuensi, mean dan Tingkat Capaian Responden (TCR)

Tabel 1. Pengaruh Variabel Komitmen Organisasi (Komitmen afektif, komitmen kontinuitas dan komitmen normatif) terhadap Kinerja Perangkat Nagari dalam Pengelolaan Keuangan Nagari Model Summary ${ }^{\mathrm{b}}$

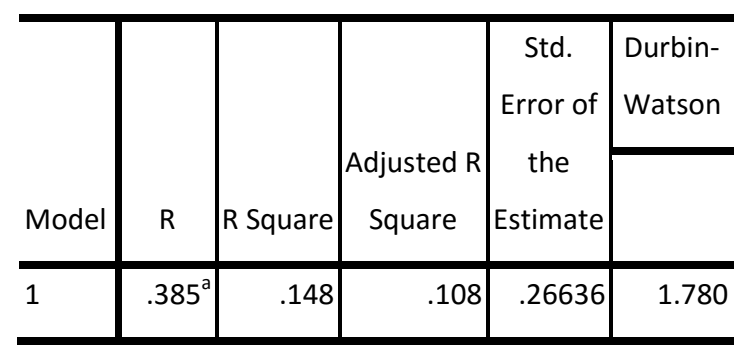

a.Predictors: (Constant), X3, X2, X1

b. Dependent Variable: $Y$

Sumber : Hasil penelitian olah data 2019 
Tabel 2. Hasil uji Anova Pengaruh variabel Komitmen Organisasi Terhadap Kinerja Perangkat Nagari dalam Pengelolaan Keuangan Nagari

\begin{tabular}{lrrrrr}
\multicolumn{7}{c}{ ANOVA } \\
\hline & Sum of & \multicolumn{3}{c}{ Mean } \\
Model & Squares & Df & Square & $F$ & Sig. \\
\hline Regression & .791 & 3 & .264 & 3.714 & $.016^{\mathrm{a}}$ \\
Residual & 4.541 & 64 & .071 & & \\
Total & 5.331 & 67 & & & \\
\hline
\end{tabular}

a.Predictors: (Constant), X3, X2, X1.

b. Dependent Variable: $Y$

Sumber : Hasil penelitian olah data 2019

Berdasarkan Tabel 1 di atas dapat

ketahui bahwa nilai Adjusted $R$ Square dari hasil analisis regresi adalah sebesar 0,108. Bearti besar pengaruh variabel komitmen organisasi yang berupa sub variabel diantaranya komitmen afektif, komitmen kontinuitas dan komitmen normatif secara simultan terhadap kinerja perangkat nagari dalam pengelolaan keuangan nagari adalah sebesar 10,8\%. Untuk hasil uji Anova pada Tabel 2 di atas dilihat bahwa hasil atau angka signifikansi pengaruh menunjukkan angka 0,016a dan kecil dari 0,02a. Maksudnya adalah kebenaran kesimpulan hasil uji regresi ini dapat dipercaya sampai $100 \%$. Selanjutnya, untuk jawaban rumusan masalah kedua, secara ringkas, hasil pengujian regresi untuk menjawab rumusan masalah kedua, dapat dilihat pada Tabel3 sebagai berkut:
Tabel 3. Hasil uji parsial Pengaruh variabel Komitmen Organisasi Terhadap Kinerja Perangkat Nagari dalam Pengelolaan Keuangan Nagari

\begin{tabular}{l|l|l|l|l|}
\hline $\begin{array}{l}\text { Sub } \\
\text { variabel }\end{array}$ & $\mathbf{R}$ & $\begin{array}{l}\mathbf{R} \\
\text { Square }\end{array}$ & $\begin{array}{l}\text { Adjusted } \\
\text { R Square }\end{array}$ & Sig \\
\hline $\begin{array}{l}\text { Komitmen } \\
\text { Afektif }\end{array}$ & $.267 a$ & .071 & .057 & $.028 a$ \\
Komitmen & $.314 a$ & .098 & .085 & $.009 a$ \\
Kontinuitas & & & & \\
Komitmen & $.279 a$ & .078 & .064 & $.021 a$ \\
Normatif & & & & \\
\hline
\end{tabular}

Sumber : Hasil penelitian olah data 2019

Berdasarkan Tabel 3 di atas diketahui bahwa, nilai Adjusted $R$ Square untuk sub variabel komitmen afektif adalah sebesar 0,057. Berarti pengaruh komitmen afektif terhadap pengelolaan keuangan nagari adalah sebesar 5,7\% namun tidak signifikan. Maka lebihnya sebesar 94,3\% dipengaruhi oleh variabel lain. Selanjutnya nilai Adjusted $R$ Square untuk sub variabel komitmen kontinuitas adalah sebesar 0,085. Berarti pengaruh komitmen kontinuitas terhadap pengelolaan keuangan nagari adalah sebesar $8,5 \%$ signifikan. Kemudian nilai Adjusted $R$ Square untuk sub variabel komitmen normatif adalah sebesar 0,064. Hal ini memiliki arti bahwa pengaruh komitmen normatif terhadap pengelolaan keuangan nagari adalah sebesar $6,4 \%$ namun tidak signifikan. Pengaruh dikatakan signifikan apabila nilai signifikansi di bawah 0,02. 


\section{Pembahasan}

Hasil penelitian ini menjelaskan mengenai pengaruh komitmen organisasi terhadap kinerja perangkat nagari dalam pengelolaan keuangan nagari di Kecamatan X Koto Singkarak dan Junjung Sirih baik secara simultan maupun secara sendiri-sendiri. Secara berturut-turut sub vairabel komitmen afektif, komitmen kontinuitas dan komitmen normatif menghasilkan angka signifikansi 0,028a, 0,009a dan 0,021a dan secara simultan nilai Adjust R Square sebesar 0,108 hal tersebut memiliki arti bahwa kontribusinya adalah sebesar $10,8 \%$ dan nilai $\mathrm{R}$ sebesar 0,385 yang berarti bahwa kekuatan variabel komitmen organisasi terhadap kinerja perangkat nagari sebesar 38,5\%. Berdasarkan penjelasan tersebut maka ditarik kesimpulan bahwa baik secara bersama-sama ataupun secara sendirsendiri komitmen organisasi memiliki pengaruh secara signifikan terhadap kinerja perangkat nagari dalam pengelolaan keuangan nagari di Kecamatan X Koto Singkarak dan Junjung Sirih.

Berdasarkan uji t (parsial) nilai Adjust $R$ Square masing-masing sub variabel secara berurutan yaitu sebesar 0,057(5,7\%) untuk komitmen afektif, $0,085(8,5 \%)$ untuk komitmen kontinuitas, dan $0,064(6,4 \%)$ untuk sub variabel komitmen normatif. Maka dapat ditarik kesimpulan bahwa kontribusi komitmen afektif terhadap pengelolaan keuangan nagari sebesar $5,7 \%$ tidak signifikan, komitmen kontinuitas sebesar 8,5\% signifikan, dan komitmen normatif sebesar $6,4 \%$ tidak signifikan.

Berdasarkan uji f (simultan) pengaruh komitmen organisasi terhadap kinerja dapat membuktikan dan ikut memperkuat teori-teori dan temuan penelitian yang sudah ada, seperti dikemukakan oleh Penelitian ini telah membuktikan teori Meyer dan Allen (2002) menjelaskan komitmen organisasi terbagi tiga bagian penting yang turut serta dalam pembentukan komitmen organisasi, yaitu komitmen afektif menunjukan adanya suatu keterikatan emosional dan keterlibatan langsung dalam organisasi, komitmen berkelanjutan menunjukkan adanya pertimbangan biaya jika tidak lagi dalam organisasi tersebut, dan komitmen normatif mencerminkan persepsi kewajiban untuk tetap berada dalam organisasi . Komitmen organisasi secara umum dapat diartikan sebagai hubungan psikologis antar karyawan dan organisasinya yang membuatnya kurang memungkinkan bahwa karyawan secara sukarela akan meninggalkan organisasi meski bagaimanapun keadaan organisasi tersebut. Secara luas komitmen organisasi 
diartikan sebagai sikap kerja yang multidimensi (Mayer and Allen , 1984). Hal tersebut dapat dipahami bahwa semakin baik komitmen organisasi karyawan maka mereka akan bertahan dalam organisasi tersebut meski bagaimanapun kondisi organisasinya serta berkomitmen untuk menciptakan kinerja yang baik.

Selanjutnya jika dilihat dari hasil pengaruh sub variabel komitmen organisasi secara simultan penelitian ini menolak teori Mayer dan Allen (2002) menjelaskan komitmen organisasi terbagi tiga bagian penting yang turut serta dalam pembentukan komitmen organisasi, yaitu komitmen afektif menunjukan adanya suatu keterikatan emosional dan keterlibatan langsung dalam organisasi, komitmen berkelanjutan menunjukkan adanya pertimbangan biaya jika tidak lagi dalam organisasi tersebut, dan komitmen normatif mencerminkan persepsi kewajiban untuk tetap berada dalam organisasi . Komitmen organisasi secara umum dapat diartikan sebagai hubungan psikologis antar karyawan dan organisasinya yang membuatnya kurang memungkinkan bahwa karyawan secara sukarela akan meninggalkan organisasi meski bagaimanapun keadaan organisasi tersebut.
Penelitian ini juga menolak teori Robbins dalam Arina Nurandini dan Eisha Lataruva (Jurnal Studi Manajemen dan Organisasi, 2014) terdapat 3 macam dimensi komitmen organisasional yang ikut berpengaruh terhadap kinerja yaitu: Komitmen Afektif, Komitmen Normatif, dan Komitmen Berkelanjutan.

Penelitian ini juga membuktikan teori oleh Carsten dan Spector dalam Sopiah (2008: 179) semakin meningkat komitmen organisasi maka akan berpengaruh pada karyawan sendiri, yaitu karyawan akan tetap berada dalam organisasi dan akan selalu berusaha meningkatkan kinerjanya menjadi lebih baik. Hal tersebut menjelaskan bahwa semakin baik komitmen karyawan maka akan meningkatkan kinerja mereka menjadi lebih baik. Dapat dipahami bahwa komitmen organisasi memiliki pengaruh terhadap kinerja karyawan.

\section{Kesimpulan}

Berdasarkan hasil penelitian yang penulis lakukan maka dapat diambil kesimpulan sebagai berikut, diantaranya:

1. Berdasarkan uji f (simultan) komitmen organisasi (X) (komitmen afektif, komitmen kontinuitas dan komitmen normatif) memiliki pengaruh positif sebesar $10,8 \%$ dan 
signifikan terhadap kinerja perangkat nagari dalam pengelolaan keuangan nagari di Kecamatan $\mathrm{X}$ Koto Singkaran dan Junjung Sirih.

2. Berdasarkan uji $\mathrm{t}$ (parsial) komitmen kontinuitas berpengaruh positif sebesar 8,5\% dan signifikan, namun variabel komitmen afektif dan komitmen normatif berpengaruh positif yaitu beruturut-turut memiliki pengaruh 5,7\% dan 6,4\% namun tidak signifikan terhadap kinerja perangkat nagari dalam pengelolaan keuangan nagari di Kecamatan $\mathrm{X}$ Koto Singkarak dan Junjung Sirih. Hasil ini menolak teori Meyer dan Allen (2002) menjelaskan komitmen organisasi terbagi atas tiga bagian penting yang turut serta dalam pembentukan komitmen organisasi, yaitu komitmen afektif menunjukan adanya suatu keterikatan emosional dan keterlibatan langsung dalam organisasi, komitmen berkelanjutan menunjukkan adanya pertimbangan biaya jika tidak lagi dalam organisasi tersebut, dan komitmen normatif mencerminkan persepsi kewajiban untuk tetap berada dalam organisasi.

\section{Rekomendasi}

1. Untuk Kabupaten Solok Khususnya Kecamatan X Koto Singkarak dan Junjung Sirih bagi perangkat agar lebih bersungguh-sungguh dan meningkatkan aspek komitmen afektif, komitmen kontinuitas dan komitmen normatif dalam pengelolaan keuangan nagari agar terciptanya kinerja yang memuaskan dan lebih baik, agar mampu meningkatkan kinjerja, serta menciptakan kinerja yang memuaskan dan lebih baik kedepannya. Dan bagi pemerintah daerah agar dapat memberikan reward kepada perangkat nagari yang memiliki kinerja yang bagus, tujuannya adalah agar dapat mendongkrak komitmen dan semangat mereka dalam bekerja sehingga mereka dapat terus bertahan dan loyal terhadap organisasinya.

2. Hasil penelitian ini masih memiliki kekurangan dan kelemahan tertentu, peneliti menyadari hal itu, maka oleh sebab itu diharapkan kepada peneliti selanjutnya agar dapat membantu menyempurnakan penelitian ini dengan meneliti dengan lebih mendalam serta melibatkan berbagai variabel lainnya yang berkemungkinan dapat mempengaruhi kinerja perangkat nagari dalam pengelolaan keuangan nagari di Kecamatan $\mathrm{X}$ Koto Singkarak dan Junjung Sirih. 


\section{DAFTAR KEPUSTAKAAN}

\section{Buku dan Jurnal}

Amirul Akbar dkk. (2017). Pengaruh Komitmen Organisasional

Terhadap

Kinerja (Studi Pada Karyawan Pt

Pelindo Surabaya). Jurnal Administ rasi Bisnis (JAB)|Vol. 47 No.2 Juni 2017| administrasibisnis.studentjou rnal.ub.ac.id

Arina Nurandini dan Eisha Lataruva. (2014). Analisis Pengaruh Komitmen Organisasi Terhadap Kinerja Karyawan (Studi Pada Pegawai Perum Perumnas Jakarta). Jurnal Studi Manajemen \& Organisasi 11 (2014) Juni 7891.http://ejournal.undip.ac.id/index. php/smo

Bintoro dan Daryanto. (2017). Manajemen Penilaian Kinerja Karyawan. Yogyakarta : Penerbit Gava Media

Edison, Emron dkk. (2016). Manajemen Sumber daya manusia (strategi dan perubahan dalam rangka meningkatkan kinerja pegawai dan organisasi). Bandung: Penerbit alfabeta

Edi Sutrisno. (2015). Manajemen Sumber Daya Manusia. Jakarta: Kencana.
Harbani Pasolong. (2010). Kepemimpinan Birokrasi. Bandung: Alfabeta.

Ida Respatiningsih. (2015). Pengaruh Komitmen Organisasi, Motivasi, Kapabilitas Dan Kepuasan Kerjaterhadap Kinerja Pegawai (Studi Empirik Pada Inspektorat Kabupaten Pemalang). Serat Acitya-Jurnal IlmiahUNTAG Semarang ISSN : 2302-2752, Vol. 4 No. 3, 2015

Jajang Adiftiya. (2014). Pengaruh Komitmen Organisasi Terhadap Kinerja Karyawan Pada Pt. Bukit Makmur Mandiri Utama Site Kideco Jaya Agung Batu Kajang Kabupaten Paser. eJournal Ilmu Administrasi Bisnis, Volume 2, Nomor 4, 2014: 833-845

John P. Meyer dkk. (2002). Komitmen Afektif, Kelanjutan, dan Normatif untuk Organisasi, Meta- analisis Antesesden, Berkolerasi dan Konsekuensi. Jurnal Perilaku Kejuruan 61. 20-52 (2002)

Juklak Bimkon Pengelolaan Keuangan Desa. (2015). Petunjuk Pelaksanaan Bimbingan \& Konsultasi Pengelolaan Keuangan Desa. Deputi Bidang Pengawasan 
Penyelenggaraan Keuangan

Daerah.

Natalie J. Allen dan John P. Meyer. (1996).

Komitmen Afektif, Kelanjutan, dan

Normatif Terhadap Organisasi:

Pemeriksaan Validitas

Membangun. Jurnal Perilaku

Vokasi 49, 252-276 (1996). Pasal

No. 0043

Ranty Sapitri. (2016). Pengaruh Komitmen

Organisasi Terhadap Kinerja Karyawan Perusahaan Listrik Negara Area Pekanbaru. Jom Fisip

Vol. 3 No. 2 - Oktober 2016

Ratna Ekawati. (2013). Pengaruh Komitmen Organisasi Terhadap Kinerja Karyawan (Studi pada PT. ATRI DISTRIBUSINDO Bandung). SMART - Study \& Management Reseach | Vol X, No.3 - 2013.

Syamsir. (2017). "Model Pembinaan Kapasitas Aparatur Pemerintahan Nagari dalam Pengelolaan Keuangan Nagari di Kabupaten Tanah Datar Provinsi SumateraBarat.LaporanPenelitian. Padang: UniversitasNegeriPadang.

S Syamsir. (2016). The Influence of Public Service Motivation of Service Quality of Civil Servants in West Sumatra Indonesia. European
Juornal of Economic of Bussines Studies 2 (2), 33-41.

S Syamsir, S Nojeng. (2018). Peningkatan Efisiensi Bahan Bakar Pada Pembangkit Tenaga Diesel (PLTD) Melalui Perbaikan Faktor Daya Beban : (Alternatif baru pengurangan emisi CO2). Seminar Nasional Hasil Penelitian (SN2PM PNUP).

S Syamsir. (2015). Public Service Motivtion among Indonesian Employees : A Critical Review Toward the Psm Theory. European Journal of Social Science Education and Research 2 (40), 133-142

S Syamsir. (2019). Analisis Spasial efektivitas Fogging di Wilayah Kerja Puskesmas Makroyan, Kota Samarinda. Jurnal Nasional Ilmu Kesehatan 1 (2).

Wirawan. (2009). Evaluasi Kinerja Sumber Daya Manusia (Teori, aplikasi dan penelitian). Jakarta : Salemba Empat

Yusuf, Murtiono.(2016). Modul Tata Kelola Keuangan Desa.Yogyakarta : Infest.

\section{Peraturan Perundang- undangan}

Undang-UndangNomor 6 Tahun 2014 Tentang Desa 
Peraturan Menteri Dalam Negeri Nomor 113 Tahun 2014 Tentang Pedoman Pengelolaan Keuangan Desa

Peraturan Daerah Kabupaten Solok Nomor 7 Tahun 2006 tentang Pemerintahan Nagari

PERMENDAGRI No 114/ Tahun 2014 Tentang Pedoman Pembangunan Desa

Peraturan Daerah Provinsi Sumatera Barat Nomor 7 Tahun 2018 tentang Nagari

\section{Berita}

Amel, 2017. "Minimalisir Kesalahan dan Penyelewengan, Kab. Solok Terapkan Sistem Berbasis IT". https://mediaharapan.com/minimalisirkesalahan-dan-penyelewengan-kabupatensolok-terapkan-sistem-berbasis-it/. Di akses pada tanggal 10 Juni 2018.

Ott Tim Saber Pungli Polres Solok, 2017. "Penangkapan 2 Perangkat Nagari Aripan Terkait Pungli Dana Pengurusan Sertifakat Prona". http://www.sumbarsatu.com/berita/16498penangkapan-2-perangkat-nagari-aripanterkait-pungli-dana-pengurusan-sertifakatprona. Di akses pada tanggal 17 Juni 2018. 